\title{
Pembelajaran Double Loop Problem Solving Terhadap Kemampuan Pemecahan Masalah Matematis
}

\author{
Oktavia Irma Pratama ${ }^{1}$, Suherman ${ }^{2}$ \\ ${ }^{1}$ SMP Bina Mulya Bandar Lampung. Jalan Badak Sukamenanti, Kedaton, Bandar Lampung \\ 35123, Indonesia. \\ 2 Universitas Islam Negeri Raden Intan Lampung. Jalan Endro Suratmin, Sukarame, Bandar \\ Lampung 35133, Indonesia. \\ *Corresponding Author. E-mail: Oktaviairmapratama@gmail.com
}

Received : 11-07-2018; Revised : 07-08-2018; Accepted : 03-09-2018

\begin{abstract}
Abstrak
Tujuan penelitian ini adalah untuk mengetahui pengaruh model pembelajaran Double Loop Problem Solving (DLPS) terhadap kemampuan pemecahan masalah matematis peserta didik. Penelitian ini merupakan jenis penelitian Quasi Experimentasi Design. Teknik pengambilan sampel yang digunakan adalah teknik acak kelas. Sampel dalam penelitian ini adalah peserta didik kelas VII B sebagai kelas eksperimen dan kelas VII E sebagai kelas kontrol. Instrumen yang digunakan untuk mengumpulkan data adalah tes pemecahan masalah matematis berupa soal uraian. Teknik analisis data penelitian ini adalah uji normalitas, uji homogenitas dan uji hipotesis menggunakan uji-t satu pihak. Berdasarkan hasil analisis uji-t satu pihak dengan taraf signifikan $5 \%$ dengan keterangan $t_{\text {hitung }} \leq t_{\text {tabel }}$, Sehingga hasil penelitian dapat disimpulkan bahwa terdapat pengaruh model pembelajaran Double Loop Problem Solving (DLPS) terhadap kemampuan pemecahan masalah matematis.
\end{abstract}

Kata kunci: Double Loop Problem Solving, Pemecahan Masalah Matematis.

\begin{abstract}
The purpose of this study was to determine the effect of learning models Double Loop Problem Solving (DLPS) to the ability problem solvimg mathematical students. This research was a quantitative research type of quasi experiment. The sampling technique that used was random class technique. The sampel in this research was the VII B grade as a experimental class and the VII E grade as a control class. Data analysis technique of this research was normality test, homogeneity test and hypothesis test by using one-party t-test. Based on the result of t-test analysis of one party with significant level 5\% with description $t_{\text {hitung }} \leq t_{\text {tabel }}$ So the result of the research can be concluded that there was influence of learning models Double Loop Problem Solving (DLPS) to the ability problem solving of mathematically.
\end{abstract}

Keywords: Double Loop Problem Solving, Mathematical Problem Solving.

\section{PENDAHULUAN}

Mendidik tidak hanya berfokus pada penanaman aspek kognitif yang dituntut untuk menguasai materi yang dipelajari saja, melainkan pada zaman modern kini justru penilaian peserta didik dititik beratkan pada penilaian proses serta sikap peserta didik. Berangkat dari persoalan ini, para pendidik bahkan hingga calon pendidik pun dituntut untuk melakukan pengembangan pada proses pembelajaran di kelas baik dari segi bahan ajar serta model yang digunakan untuk dapat meningkatkan minat, penalaran, hasil belajar, hingga terhadap kemampuan berfikir matematis peserta didik. Hal demikian dilakukan karena tidak terlepasnya pula proses pendidikan yang sangat kompleks (Anggoro, 2015; Syazali, 2015).

Salah satu model pembelajaran kooperatif yang dinilai dapat 
berpengaruh baik terhadap proses belajar terutama terhadap kemampuan pemecahan masalah matematis siswa salah satunya adalah Double Loop Problem Solving (DLPS). Dari beberapa studi terdahulu, pembelajaran dengan menggunakan model Double Loop Problem Solving (DLPS) dapat meningkatkan kualitas pembelajaran dan hasil belajar siswa dalam pemecahan masalah (Roliyani, 2016). Selain itu penelitian lainnya menghasilkan bahwa model Double Loop Problem Solving (DLPS) dapat meningkatkan prestasi belajar siswa dalam pemecahan masalah matematis (Firman Aryansyah, 2015). DLPS sendiri merupakan sebuah pengembangan dari model Problem Solving dimana pada model DLPS lebih menitik beratkan pada pencarian sebuah sebab dari sebuah masalah (Shoimin, 2013). Sejalan dangan hal ini, pembelajaran DLPS dapat menekankan bagi para peserta didik untuk menjadi individu yang aktif didalam kelas sehingga tidak hanya menjadi pengamat semata (Haryati, 2017). Selain itu, pembelajaran yang dilakukan dalam DLPS adalah menuntut siswa untuk mengola pemikirannya dalam mencari sebuah penyebab dari sebuah masalah yang dihadapi (Shoimin, 2013). Dalam hal serupa, pembelajaran DLPS terbukti dapat memberikan dampak yang baik terhadap hasil belajar maupun terhadap kemampuan pemecahan masalah matematis (Dwijananti et al., 2016). Kemudian penelitian selanjutnya didapatkan bahwa DLPS sangat berpengaruh dalam membuat siswa memiliki kemampuan berfikir kritis (Rusmin, 2016).

Pemecahan masalah matematis, merupakan sebuah aktifitas dasar yang dimiliki oleh tiap individu dalam menyelesaikan masalah-masalah yang dihadapi, terutama dalam pelajaran matematika selain itu bahwa dengan memiliki kemampuan pemecahan masalah secara matematis yang tinggi dapat dijadikan sebuah tumpangan untuk dapat memahami konsep-konsep matematika dengan mudah (Yanti \& Syazali, 2016). Oleh sebabnya, dalam mempalajari matematika tidak cukup hanya berfokus pada pemahan konsepnya saja melainkan didalamnya tedapat banyak proses yang tejadi dan tentunya diperlukan pemahaman matematis yang baik (Putra, 2017).

Berangkat dari ungkapan-ungkapan para ahli dan peneliti terdahulu, bahwa dalam mempelajari matematika tidak cukup hanya sebuah pemahaman konsep semata, melainkan terdapat pula subuah kemampuan matematis yang wajib dimiliki oleh peserta didik, maka sebuah hal yang membedakan dari penelitian ini dengan penelitian-penelitian terdahulu yang utama adalah lebih memfokuskan pada sebab-sebab dari sebuah masalah sebagaimana yang tertera pada langkahlangkah Double Loop Problem Solving serta hal yang membedakan DLPS dengan Problem solving biasa yang hanya berfokus pada pemecahan sebuah masalah tanpa memfokuskan pada sebabsebabnya. Dengan demikian, penggunaan Double Loop Problem Solving dalam penelitian ini juga sekaligus dapat meningkatkan kemampuan matematis peserta didik sebagaimana sebuah kemampuan yang harus dimiliki oleh peserta didik. Untuk membuktikan hal ini, untuk itu diperlukan sebuah penelitian mengenai "Pembelajaran Double Loop Problem Solving terhadap Kemampuan Pemecahan Masalah Matematis Pembelajaran Double Loop Problem Solving terhadap Kemampuan Pemecahan Masalah Matematis".

\section{METODE}

Metode pada penelitian ini adalah eksperimen dengan menggunakan jenis penelitian Quasi Experimentasi Design yaitu yang memiliki kelompok kontrol, tetapi tidak dapat berfungsi sepenuhnya 
Desimal, 1 (3), 2018 - 287

Oktavia Irma Pratama, Suherman

untuk mengontrol variabel-variabel luar yang mempengaruhi pelaksanaan eksperimen (Sugiyono, 2011).

Adapun desain penelitian ini terlihat pada Tabel 1 .

Tabel 1. Desain Penelitian

\begin{tabular}{ccc}
\hline Kelompok & Treatmen & Post-test \\
Eksperimen & $\mathrm{X}_{1}$ & $\mathrm{O}_{1}$ \\
Kontrol & $\mathrm{X}_{2}$ & $\mathrm{O}_{2}$ \\
\hline
\end{tabular}

(Sumber: Sugiyono, 2015)

Keterangan:

$X_{1}=$ Perlakuan terhadap kelas eksperimen dengan pembelajaran menggunakan model pembelajaran DLPS.

$X_{2}=$ Perlakuan terhadap kelompok kelas kontrol dengan pembelajaran ekspositori

$O_{1}=$ Post-Test diberikan kepada kelas eksperimen.

$\mathrm{O}_{2}=$ Post-Test diberikan kepada kelas kontrol.

Uji Instrumen tes mengacu pada kiteria Validitas Soal, Reliabilitas $\left(r_{11} \geq 0,7\right)$, Uji Tingkat kesukaran $(0,3 \leq P \leq 0,7)$, dan Uji Daya beda $(D \geq 0,3)$ (Budiyono, 2011; Sugiyono, 2011). Sedangkan Asumsi analisis data yang digunakan yaitu uji normalitas dan uji homogenitas dengan teknik analisis data dalam pengujian hipotesis menggunakan $u j i-t$. Pengujian uji normalitas menggunakan uji Liliefors dengan rumus sebagai berikut:

dengan

$$
L_{\text {hitung }}=\max \left|F\left(Z_{i}\right)-S\left(Z_{i}\right)\right|
$$

$$
L_{\text {tabel }}=L_{(\alpha, n)}
$$

Dengan hipotesis:

$H_{0}$ : data mengikuti sebaran normal

$H_{1}$ : data tidak mengikuti sebaran normal

Uji homogenitas dapat dicari dengan menggunakan uji kesamaan 2 varians dengan rumus:

$H_{1}$ : Ada pengaruh varians 1 dan varians 2

$H_{0}$ : Tidak ada pengaruh antara varians 1

dan varians 2

Dengan rumus $F_{\text {hitung: }}$

$$
F=\frac{\text { Varians Terbesar }}{\text { Varians Terkecil }}
$$

dengan taraf signifikan $\alpha=0,05$. Sedangkan mencari $F_{\text {tabel }}$ :

$$
\begin{aligned}
& F_{\text {tabel }}=F_{\frac{1}{2 \alpha}} \\
& \text { Dengan pengujian } H_{0} \text { jika } \\
& F_{\text {hitung }} \leq F_{\text {tabel }} \text { maka } H_{0} \text { adalah }
\end{aligned}
$$

Homogen. Sedangkan untuk mencari uji-t digunakan rumus sebagai berikut:

$t_{\text {hitung }}=\frac{\bar{X} 1-\bar{X} 2}{\sqrt{\frac{\left(n_{1}-1\right) s_{1}^{2}+\left(n_{2}-1\right) s_{1}^{2}}{n_{1}+n_{2}-2}\left(\frac{1}{n_{1}}+\frac{1}{n_{2}}\right)}}$

Keterangan:

$\overline{\mathrm{X}}_{1}=$ Nilai rata-rata kemampuan pemecahan masalah matematis kelas eksperimen

$\overline{\mathrm{X}}_{2}=$ Nilai rata-rata kemampuan pemecahan masalah matematis kelas kontrol

$n_{1}=$ Banyaknya peserta didik kelas eksperimen

$n_{2}=$ Banyaknya peserta didik kelas kontrol

$s_{1}^{2}=$ Varians data kelompok eksperimen

$s_{2}^{2}=$ Varians data kelompok kontrol Adapun langkah-langkah pengujian hipotesis ini sebagai berikut:

$H_{o}: \mu_{1} \leq \mu_{2}$ (Rata-rata kemampuan pemecahan masalah matematis pada peserta didik yang menggunakan model pembelajaran Double Loop Problem Solving (DLPS) kurang dari atau sama dengan rata-rata pemecahan masalah matematis peserta didik yang menggunakan model pembelajaran ekspositori)

$H_{1}: \mu_{1}>\mu_{2}$ (Rata-rata pemecahan masalah matematis pada peserta didik yang menggunakan model pembelajaran Double Loop Problem Solving (DLPS) lebih tinggi dengan rata-rata pemecahan masalah matematis peserta didik yang menggunakan model pembelajaran ekspositori).

Dengan Kriteria Uji:

Jika $\left|t_{\text {hitung }}\right| \leq t_{\text {tabel }}$, maka $H_{0 \text { diterima }}$. 


\section{HASIL DAN PEMBAHASAN}

Hasil dari penerapan pembelajaran Double Loop Problem Solving dapat diterima dengan baik oleh siswa karena pada dasarnya siswa mempunyai kemampuan matematika yang baik. Namun terbatasnya frekuensi peneliti dalam menerapkan pembelajaran Double Loop Problem Solving dikelas eksperimen maka pengaruh penggunaan pembelajaran Double Loop Problem Solving tampak kurang signifikan pada pencapaian kemampuan kognitif siswa. Selain itu fakta yang ditemukan peneliti yaitu mengingat bahwa siswa dituntut untuk dapat menemukan atau memecahkan permasalahan yang diberikan oleh guru, sehingga siswa akan lebih memahami materi dan tidak mudah lupa materi yang sudah diajarkan sebelumnya.

Setelah data kemampuan pemecahan masalah matematis peserta didik terkumpul baik dari kedua kelas eksperimen maupun dari kelas kontrol diperoleh terlihat pada Tabel 2 .

Tabel 2. Deskripsi Data Kemampuan Pemecahan Masalah Matematis

\begin{tabular}{lccccc}
\multicolumn{1}{c}{ Kelas } & $\mathbf{X}_{\text {maks }}$ & $\mathbf{X}_{\text {min }}$ & $\overline{3}$ & Ukuran Tendensi Sentral \\
Eksperimen & 90 & 25 & 57,6 & 50 & Mo \\
Kontrol & 75 & 25 & 48,6 & 50 & 40 \\
\hline
\end{tabular}

Setelah

dilaksanakan pembelajaran, pada kelas Eksperimen dan Kelas Kontrol dilakukan evaluasi akhir untuk mengetahui kemampuan pemecahan masalah matematis peserta didik sebagai pengumpulan data hasil evaluasi akhir diperoleh bahwa pada kelas eksperimen dengan tes soal essai pada kemampuan pemecahan masalah matematis didapat nilai terbesar 90 dan nilai terkecil 25, nilai tengah (Me) 50, nilai terbanyak yang didapat peserta didik (Mo) adalah 40 dan rata-rata nilai peserta didik adalah 57,6. Sedangkan pada kelas Kontrol hasil tes kemampuan pemahaman konsep matematis didapat nilai terbesar 75 dan nilai terkecil 25, nilai rata-rata yang diperoleh peserta didik adalah 48,6, dengan Median 50 serta nilai yang sering muncul adalah 50 . Berdasarkan hal ini dapat disimpulkan bahwa kemampuan pemecahan masalah peserta didik kelas eksperimen (mendapat pembelajaran Double Loop
Problem Solving) lebih baik dari peserta didik kelas kontrol (Mendapat model pembelajaran ekspositori).

Selanjutnya dilakukan analisis uji asumsi dengan uji normalitas kemampuan pemecahan masalah matematis peserta didik pada kelas eksperimen dengan hasil skor kelas eksperimen sebesar 57,6 dengan $L_{\text {hitung }}=0.164$ dan $L_{\text {tabel }}=0.173$ hal ini menunjukan bahwa $\boldsymbol{L}_{\text {hitung }} \leq \boldsymbol{L}_{\text {tabel }}$ sehingga dapat disimpulkan data berdistribusi normal. Dan kelas control adalah sekor kelas kontrol sebesar 48,5 dengan $\quad L_{\text {hitung }}=\mathbf{0 . 1 5 5}$ dan $\boldsymbol{L}_{\text {tabel }}=\mathbf{0 . 1 7 3}$ hal ini menunjukkan bahwa $\boldsymbol{L}_{\text {hitung }} \leq \boldsymbol{L}_{\text {tabel }}$ sehingga dapat disimpulkan data berdistribusi normal. Berikut hasil rekapitulasi perhitungan uji normalitas pemecahan masalah matematis pada kelas eksperimen dan kelas kontrol.

Tabel 3. Hasil Perhitungan Uji Normalitas

\begin{tabular}{cccc} 
Kelas & $\boldsymbol{L}_{\text {hitung }}\left(L_{(\alpha, n)}\right)$ & $\boldsymbol{L}_{\text {tabel }}$ & Keterangan \\
Eksperimen & 0,164 & 0.173 & Normal \\
Kontrol & 0.155 & 0.173 & Normal \\
\hline
\end{tabular}


Berdasarkan perhitungan hasil uji coba normalitas Kemampuan Peecahan masalah matematis pada kelas eksperimen dan kelas kontrol dengan taraf sigifikansi $\alpha=5 \%$, diperolah bahwa nilai dari $L_{\text {hitung }}$ dari setiap kelompok kurang dari $L_{\text {tabel }}$ sehingga hipotesis nol dari setiap kelompok diterima. Dapat disimpulkan bahwa data yang diperoleh dari setiap kelompok berasal dari populasi yang berdistribusi normal. Uji Kesamaan Dua Varians kemampuan Pemahaman Konsep Matematis
Untuk mengetahui apakah kedua skor memiliki karakter yang sama atau berbeda maka diperlukan uji F. Pengujian variansi ini yaitu membandingkan varians terbesar dan varians terkecil. Jika $F_{\text {hitung }} \leq F_{\text {tabel }}\left(\sigma_{1}, \sigma_{2}\right)$ didapat dari distribusi dengan peluang $\frac{1}{2} \alpha$ sedangkan derajat kebebasan $\sigma_{1}\left(n_{1}-1\right)$ dan $\sigma_{2}\left(n_{2}-2\right)$ masing-masing sesuai dengan $d k$ pembilang dan $d k$ penyebut. Hasil pengujian varians dengan taraf signifikan $\alpha=5 \%$ dapat dilihat pada Tabel 4 .

Tabel 4. Hasil Perhitungan Uji Kesamaan Dua Varians

\begin{tabular}{ccccc}
\hline Kelas & Varians & $\boldsymbol{F}_{\text {hitung }}$ & $\boldsymbol{F}_{\text {tabel }}$ & Keterangan \\
Eksperimen & 402,8 & 1,54 & 1,98 & Homogen \\
Kontrol & 261,5 & & & \\
\hline
\end{tabular}

Berdasarkan Tabel 4, hasil perhitungan skor Kemampuan Pemahaman konsep matematis diperoleh $F_{\text {hitung }}=1,54 \quad$ dan $\quad F_{\text {tabel }}=1,98$. Menunjukan bahwa $F_{\text {hitung }} \leq F_{\text {tabel }}$ dengan hal ini dapat disimpulkan bahwa $H_{0}$ diterima atau sempel berasal dari populasi yang memiliki varians sama. Untuk menguji perbedaan Kemampuan Pemahaman konsep matematis peserta didik digunakan rumus uji-t, karena data yang diperoleh berdistribusi normal dan memiliki nilai varians sama, maka rumus yang digunakan sebagai berikut dengan besaran $d k=n_{1}+n_{2}-2$, harga $t_{\text {tabel }}$ dihitung $d k=25+25-2=48$ maka harga $t_{\text {tabel }}=2,011$ dengan taraf signifikansi 5\%. Hasil perhitungan dapat dilihat pada Tabel 5. berikut ini:

Tabel 5. Hasil Perhitungan Uji Hipotesis

\begin{tabular}{ccccc}
\hline Kelas & Rata-Rata $(\boldsymbol{x})$ & $\boldsymbol{t}_{\text {tabel }}\left(\boldsymbol{t}_{\boldsymbol{a}, \boldsymbol{d} \boldsymbol{b}}\right)$ & $\boldsymbol{t}_{\text {hitung }}$ & Keterangan \\
Eksperimen & 57,6 & 1,677 & 1,746 & Tolak $\mathrm{H}_{0}$ \\
Kontrol & 48,6 & & & \\
\hline
\end{tabular}

Berdasarkan Tabel 5, perhitungan diperoleh $\quad t_{\text {hitung }}=1,746 \quad$ dan $t_{\text {tabel }}=1,677$ sehingga $t_{\text {hitung }}>t_{\text {tabel }}$, yang berarti $\mathrm{H}_{0}$ ditolak yang berarti kemampuan pemecahan masalah matematis dengan pembelajaran Double Loop Problem Solving lebih tinggi dari model pembelajaran ekspositori. Hal ini didukung dengan hasil penelitian sebelumnya bahwa yang mengungkapkan model pembelajaran DLPS memberikan hasil yang lebih baik darip ada pembelajaran secara konvensional (Jufri, 2015). Sejalan dengan penelitian ini, hal serupa juga ditemui bahwa pembelajaran dengan menggunakan model Problem solving dapat meningkatkan mutu pembelajaran (Syazali, 2015). lebih jelas lagi, pembelajaran Double Loop Problem Solving terbukti membawa perubahan kearah positif terhadap kemampuan berfikir matematis siswa serta hasil belajar dan keterampilan berfikir kritis siswa sebagaimana teori serta ungkapan oleh para peneliti terdahulu bahwa dengan memfokuskan permasalahan tepat pada sebab-sebabnya seperti pada langkah awal model pembelajaran Double 
Loop Problem Solving dapat memicu pemahaman matematis peserta didik (Haryati, 2017; Jufri, 2015).

\section{SIMPULAN DAN SARAN}

Berdasarkan hasil penelitian dan pembahasan yang telah dilakukan peneliti memperoleh kesimpulan bahwa kemampuan pemecahan masalah matematis peserta didik yang menggunakan model pembelajaran Double Loop Problem Solving (DLPS) lebih tinggi dari kemampuan pemecahan masalah peserta didik yang menggunakan model pembelajaran ekspositori.

Berdasarkan kesimpulan di atas maka peneliti memberikan saran; (1) Pendidik hendaknya dapat menggunakan model pembelajaran yang bervariasi agar peserta didik berminat dalam pembelajaran matematika; (2) Pendidik hendaknya dapat menggunakan model pembelajaran yang sesuai dengan kebutuhan peserta didik; (3) Peneliti mengharapkan kepada pendidik agar dapat memperhatikan peserta didik yang kurang dalam pembelajaran matematika dengan melakukan pendekatan; (4) Peserta didik diharapakan dapat lebih menerima model pembelajaran baru yang lebih mendukung untuk meningkatkan hasil belajar; (5) Peserta didik harus lebih aktif dalam pembelajaran tanpa perlu merasa ragu dalam menyelesaikan suatu permasalahan atau soal-soal matematika dan perserta didik diharapkan mampu menuangkan kemampuan berpikir dalam mengerjakan soal-soal matematika yang diberikan; (6) Peserta didik diharapkan mampu menumbuhkan minat, rasa ingin tahu, dan rasa percaya diri dalam pembelajaran matematika; (7) Peserta didik diharapkan dapat menuangkan ideide kreatif yang dimiliki dalam menyelesaikan berbagai permasalahan ataupun soal-soal matematika.

\section{DAFTAR PUSTAKA}

Anggoro, B. S. (2015). Pengembangan Modul Matematika Dengan Strategi Problem Solvin Guntuk Mengukur Tingkat Kemampuan Berpikir Kreatif Matematis Siswa. Al-Jabar: Jurnal Pendidikan Matematika, 6(2), 121130.

Budiyono. (2011). Statistika Untuk Penelitian. Surakarta: Sebelas Maret University.

Dwijananti, P., Fatmala, R. I., Astuti, B., Fisika, J., Matematika, F., \& Alam, P. (2016). Penerapan Model Double Loop Problem Solving Menggunakan, 5(3), 1382-1390.

Firman Aryansyah. (2015). Optimalisasi Penggunaan Menggunakan Metode Pembelajaran Double Loop Problem Solving (DLPS) pada Pembelajaran Ekonomi Di SMA. Jurnal Ilmiah EDUKASI, 5(2), 137-142.

Haryati, E. (2017). Pengaruh Model Pembelajaran Double Loop Problem Solving Didukung Media Flashcard Terhadap Perubahan Lingkungan Fisik pada Siswa Kelas IV SDN Sumengko 4 Kabupaten Nganjuk Tahun Ajaran 2016/2017. Artikel Skripsi Universitas Nusantara PGRI Kediri. Universitas Nusantara PGRI Kediri.

Jufri, L. H. (2015). Penerapan Double Loop Problem Solving Untuk Meningkatkan Kemampuan Literasi Matematis Level 3 Pada Siswa Kelas Viii Smpn 27 Bandung. Lemma, II(1), 52-62.

Putra, F. G. (2017). Eksperimentasi Pendekatan Kontekstual Berbantuan Hands On Activity (HoA) Terhadap Kemampuan Pemecahan Masalah Matematik. Al-Jabar: Jurnal Pendidikan Matematika, 8(1), 73-80. https://doi.org/10.24042/ajpm.v8i1 .1148

Roliyani. (2016). Upaya Meningkatkan Hasil Belajar Siswa Melalui Penerapan Model Pembelajaran 
Desimal, 1 (3), 2018 - 291

Oktavia Irma Pratama, Suherman

Quantum Teaching. Jurnal Pena Edukasi, 1(6), 11-18.

Rusmin. (2016). Upaya Meningkatkan Hasil Belajar Ips Melalui Media. Jurnal Pendidikan Madrasah, 1(6), 85-100.

Shoimin, A. (2013). Model Pembelajaran Inovatif dalam Kurikulum 2013. Yogyakarta: Ar-ruzz Media.

Sugiyono. (2011). Metode Penelitian Kuantitatif Kualitatif dan R\&D. Bandung: Alfabeta.

Syazali, M. (2015). Pengaruh Model Pembelajaran Creative Problem
Solving Berbantuan Maple II Terhadap Kemampuan Pemecahan Masalah. Al-Jabar: Jurnal Pendidikan Matematika, 6(1), 91-98.

Yanti, A. P., \& Syazali, M. (2016). Analisis Proses Berpikir Siswa dalam Memecahkan Masalah Matematika Berdasarkan Langkah-Langkah Bransford dan Stein Ditinjau dari Adversity Quotient. Al-Jabar: Jurnal Pendidikan Matematika, 7(1), 63-74. 